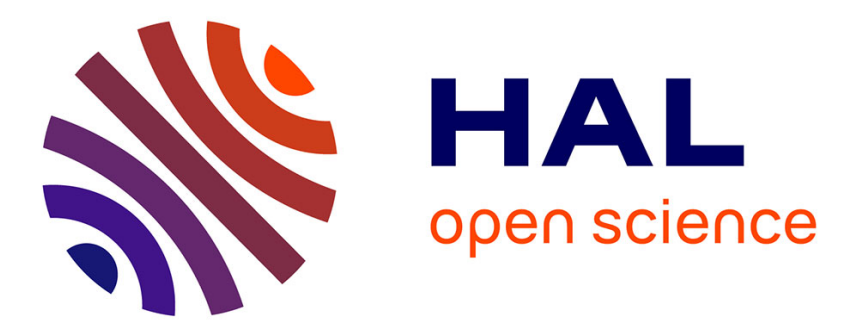

\title{
Unemployment and Substance Use in Young Adults: Does Educational Attainment Modify the Association?
}

Maria Melchior, Aude Chollet, Gulizar Elidemir, Cédric Galéra, Nadia Younès

\section{To cite this version:}

Maria Melchior, Aude Chollet, Gulizar Elidemir, Cédric Galéra, Nadia Younès. Unemployment and Substance Use in Young Adults: Does Educational Attainment Modify the Association?. European Addiction Research, 2015, 21 (3), pp.115-123. 10.1159/000365887 . hal-01148256

\section{HAL Id: hal-01148256 \\ https://hal.sorbonne-universite.fr/hal-01148256}

Submitted on 4 May 2015

HAL is a multi-disciplinary open access archive for the deposit and dissemination of scientific research documents, whether they are published or not. The documents may come from teaching and research institutions in France or abroad, or from public or private research centers.
L'archive ouverte pluridisciplinaire HAL, est destinée au dépôt et à la diffusion de documents scientifiques de niveau recherche, publiés ou non, émanant des établissements d'enseignement et de recherche français ou étrangers, des laboratoires publics ou privés. 
Unemployment and substance use in young adults: does educational attainment modify the association?

Maria Melchior ${ }^{1,2}$, Aude Chollet $^{1,2}$, Gulizar Elidemir $^{1,2}$, Cédric Galéra $^{3}$, Nadia Younès ${ }^{4}$

Running head: Unemployment and substance use in young adults.

1. INSERM, UMR_S 1136, Institut Pierre Louis d'Épidémiologie et de Santé Publique, Équipe de Recherche en Epidémiologie Sociale, F-75013, Paris, France

2. Sorbonne Universités, UPMC Univ Paris 06, UMR_S 1136, Institut Pierre Louis d’Épidémiologie et de Santé Publique, Équipe de Recherche en Epidémiologie Sociale, F75013, Paris, France

3. Child Psychiatry Department, Charles-Perrens Hospital, Univ. Bordeaux, University Victor Segalen Bordeaux 2, Bordeaux, France

4. Université de Versailles Saint-Quentin EA 4047, Centre Hospitalier de Versailles, Le Chesnay, France

Full address : Maria Melchior, IPLEPS Inserm UMRS 1136, Equipe 7 (ERES), Faculté de Médecine Pierre et Marie Curie - pôle Saint-Antoine, 27 rue de Chaligny, 75012 Paris, tel : +33177747427; fax : +33177747402 ; maria.melchior@inserm.fr

Keywords: Unemployment; educational level; socioeconomic position (SEP); substance use; young adults; epidemiology

Word count:

Abstract: 199

Text: 3603 


\section{ABSTRACT}

We studied whether patterns of substance use in relation to unemployment vary depending on educational level. Data come from 1126 community-based young adults in France (18-35 years in 2011) and their parents (TEMPO and GAZEL studies). Tobacco use (>=1 cigarette/day, 22.5\% prevalence), nicotine dependence (Fagerström test $>=2,7.1 \%$ prevalence), alcohol use (>=2 units/week, 25.3\% prevalence), alcohol abuse (WHO AUDIT $>=7$ in women and >=8 in men, $10.8 \%$ prevalence), cannabis use (>=1 time, $16.5 \%$ prevalence) and cannabis abuse (CAST >=2, 5.0\% prevalence) were assessed by interview. We conducted logistic regression analyses controlled for inverse probability weights (IPW) of unemployment, calculated based on demographics, negative life events, health, juvenile and parental characteristics. Compared to participants who were always employed, those who were unemployed and had no higher education were more likely to smoke tobacco (OR: 2.76, 95\% $\mathrm{Cl} 1.86-4.10)$, to be nicotine dependent (OR: $5.70,95 \% \mathrm{Cl} 3.03-10.73$ ), to use cannabis (OR: $2.27,95 \% \mathrm{Cl} 1.42-3.64$ ), and to abuse cannabis (OR: 3.38, 95\% $\mathrm{Cl} 1.63-7.04$ ); those who were unemployed and had higher education were especially likely to abuse alcohol (OR: 1.89, 95\% Cl 1.16-3.09). Increases in unemployment may impact population levels of substance use, particularly in young adults with low educational attainment. 


\section{Introduction}

Across industrialized countries, tobacco, alcohol and cannabis use levels in young adults are high [1-3]. This may in part be because the period between 18 and 30 years of age is characterized by role exploration, high accessibility of psychoactive substances and high tolerance of addictive behaviors [4;5]. Yet while substance use is widespread, addiction disproportionately occurs in individuals with low socioeconomic position (SEP) [6-9]. These social inequalities vary across substances (depending on the degree to which their use is accepted and the impact they may have on daily functioning)[10;11] and are probably bidirectional: 1) on the one hand, adolescents who have school and behavioral problems are at high risk of early substance use and abuse [12-14]; 2) on the other, early substance use predicts later academic failure and occupational difficulties, even after controlling for school achievement, cognitive level and behavior [14-16].

Unemployment is one aspect of individuals' SEP that could have a unique contribution to substance use [17-19]. In particular, the unemployed may be especially likely to show signs of addiction in times of economic difficulties, when it is more difficult to reintegrate the labor market. The economic crisis currently experienced by many industrialized countries, raises concerns about the possibility of an increase in population levels of substance abuse $[20 ; 21]$.

In many industrialized countries, unemployment levels are especially high in young adults [22]. Although high educational attainment generally predicts better labor market integration, with rises in joblessness such as those that occurred in recent years, even youths with high educational attainment may experience unemployment, making the unemployed an increasingly heterogeneous group [22]. Still, in the long-term, youths who achieve higher education are less likely to stay unemployed for extended periods of time [23]. Thus, for a 
majority of young adults, the level of education can be considered as "the foundation for their incomes and occupational achievements for the remainder of their adult work lives" [4]. As a result, the association between unemployment and substance use may vary depending on educational level, yet, to our knowledge this has not been studied [19]. We tested whether patterns of substance use associated with unemployment vary with educational level using data from the French TEMPO study, a community sample of young adults (18-37) surveyed in 2011. This analysis builds on prior research conducted using data collected among TEMPO study participants in 2009 , which showed that low SEP (as ascertained by an indicator combining educational level, employment situation, occupational grade and job stability) or a low or descending socioeconomic trajectory were independent predictors of high levels of tobacco and cannabis use [6;24]. To better understand substance use in relation to employment status, we focus on the three most common psychoactive substances in the general population- tobacco, alcohol, and cannabis, and systematically examine the likelihood of both regular use and abuse/dependence.

\section{Methods}

Data for this study come from two sources: young adults who took part in the 2011 assessment of the TEMPO study (www.tempo.inserm.fr) and their parents who participate in the GAZEL study (www.gazel.inserm.fr).

\section{$\underline{\text { Sample characteristics }}$}

The TEMPO (Trajectoires Epidémiologiques en Population) study was set up in 2009 to examine associations between life circumstances and substance use and mental health in young adults (see Figure 1). Study participants all have parents who also take part in the 
GAZEL epidemiological study [6;25]. The first assessment of GAZEL study participants' children took place in 1991 , when 2,585 children aged 4-16 were selected to take part in a survey of children's mental health. In 2009, we invited all youths who took part in the 1991 study (aged $22-35$ at the time) to participate in the TEMPO study - 1103 agreed, of which 752 agreed to a longitudinal follow-up [26]. In 2011, we conducted a new wave of data collection among TEMPO participants who agreed to a longitudinal follow-up and the study sample was expanded to all GAZEL study participants' offspring aged 18 to 37 years.

2011 TEMPO study participants $(n=1214)$ took part in a 30-minute phone interview assessing their health, health behaviors, access to healthcare and socioeconomic and life circumstances. Study participants unable to take part in the phone interview were invited to complete the study questionnaire online. The 2011 sample included 526 individuals who took part in the 2009 TEMPO study assessment and agreed to be followed-up $(70.1 \%$ participation) and 688 new members who were also offspring of GAZEL study participants but were not previously included in TEMPO (14.4\% participation).

Factors associated with study participation included characteristics of participants (younger age, female sex, participation in TEMPO in 2009) and of their parents (younger age, male sex, regular participation in GAZEL since 1989, high occupational grade, steady marriage, no depression). Overall, 2011 TEMPO study participants were somewhat more likely to live with a partner, have higher education and hold a managerial position than young adults of the same age in France, but the rate of lifetime unemployment was comparable to that observed in the general population.

The TEMPO study received approval from France's national committees for data protection (CCTIRS: Comité Consultatif sur le Traitement des Informations pour la Recherche en Santé: CNIL: Commission Nationale Informatique et Liberté). 


\section{Measures}

Tobacco, alcohol and cannabis use and abuse

Participants reported on their substance use and abuse over the preceding 12 months.

Tobacco use was measured by the following item: "Are you a regular smoker (at least one cigarette per day)?" (yes vs. no). Regular smokers completed the Fagerström Test for Nicotine Dependence (FTND)[27], a 5-item questionnaire which screens for nicotine dependence. Following the test authors' guidelines, all items were summed, yielding a score of 0 to 10; participants with a score $>2$ were considered to be nicotine dependent (yes vs. no).

Alcohol use was assessed using the French version of the Alcohol Use Disorders Identification Test (AUDIT), a 10-item screening test developed by the World Health Organization to match DSM IV criteria for alcohol abuse and dependence and validated against clinical diagnosis [28]. Participants who reported drinking at least 2-3 units of alcohol per week on the question "On average, how often do you drink alcohol?" were considered to be regular drinkers (yes vs. no). Alcohol abuse was ascertained by summing all 10 AUDIT items, which yielded a score between 0 and 20; following published guidelines, a score $\geq 8$ in men and $\geq 7$ in women was considered indicative of alcohol abuse or dependence [28] (referred to as alcohol abuse from here onwards; yes vs. no).

Cannabis use was ascertained by the following question "How many times have you used cannabis or marijuana"? Following other researchers, participants who had used cannabis $\geq 1$ time in the preceding 12 months were considered to be users (yes vs. no) [13]. Cannabis abuse was assessed with the Cannabis Abuse Screening Test (CAST), composed of 8 items which screen for harmful cannabis use [29](e.g., "do you smoke cannabis in the morning before going to school or work?", "do you smoke cannabis when alone?", "do you 
find it difficult to spend a day without smoking cannabis?", "have you driven a car or a motor bike after smoking cannabis?", "have you had memory problems after using cannabis?"). The CAST score ranges from 0 to 8 and following the test authors' recommendation, a score $\geq 2$ served to define cannabis abuse or dependence [29] (referred to as cannabis abuse from here onwards; yes vs. no).

\section{Unemployment and educational level}

Unemployment was ascertained by the question "Have you ever been unemployed? If so, was it in the last 2 years?" Participants who had been unemployed were additionally asked about duration of unemployment (mean =10.9 months, standard deviation=10.5).

Educational level was dichotomized based on whether participants had achieved higher education (either a 2-year university degree: ‘Diplôme d’Etudes Universitaires Générales DEUG ' or a 2-year technical or vocational degree 'Brevet de technicien supérieur- BTS' or 'Diplôme universitaire de technologie-DUT') (no higher education vs. higher education). This cutoff was used to match the increasing level of education among French youths: in 2011, 76.7\% of French adolescents in the appropriate age group graduated from high school [30]. Based on participants' experience of unemployment and educational level, we defined three groups: a) never unemployed; b) ever unemployed with no higher education, c) ever unemployed with higher education.

\section{Covariates}

Covariates included participants' demographics, negative life events, health, as well juvenile and parental characteristics potentially associated with substance use. 
Demographics were: sex (female vs. male); age ( $<30$ vs. >=30 years of age); family situation (does not live with a partner, lives with a partner and has no children vs. lives with a partner and has children); financial hardship in the preceding 12 months assessed by 5 items indicating difficulty to pay for rent/utilities, medical care, balanced and healthy meals (yes vs. no); social support measured using the Berkman Social Networks and Social Support questionnaire (insufficient vs. sufficient) [31].

Life events in the preceding 12 months were: pregnancy/abortion (yes vs. no); partner separation (yes vs. no); experience of physical or psychological violence (yes vs. no) assessed by 5 items from the French "Life events and health study" (2005-2006)[32]. Health was ascertained via psychological symptoms and chronic health problems. Psychological symptoms included: 1) anxiety and depression in the preceding 12 months measured by key symptoms of agoraphobia, panic disorder, social phobia, and general anxiety disorder as well as major depressive disorder ascertained using the MINI [33] (yes vs. no); 2) hyperactivity/inattention measured using the Adult ADHD Self Report Scale (ASRS)[34] - a WHO screening tool which includes 2 items on hyperactivity and 4 on inattention (range 0-24); four or more positive responses are considered indicative of clinically significant symptoms (yes vs. no). Chronic health problems were assessed through self-reported chronic conditions that are most frequent in young adults: diabetes, obesity, chronic digestive disease, cancer and epilepsy (>=1 vs. 0 ).

Juvenile characteristics prior to age 15 were assessed retrospectively and included exposure to parental violence, bullying, or severe lack of affection as ascertained by questions from the French SIRS study (yes vs. no) [35], antisocial personality ascertained using the MINI [33] and early smoking initiation (<=13 vs. $>13$ years of age). 
Parental characteristics were ascertained combining parental self-reports on the GAZEL study questionnaire between 1989 and 2011 ( $n=13$ measures) and TEMPO participants' retrospective reports: regular tobacco use (yes vs. no), high alcohol use (selfreported $>=3$ units of alcohol per day in men and $>=2$ units of alcohol per day in women or parental alcohol dependence as reported by TEMPO participants on the Family Interview for Genetic Studies [36]). Parental household income was reported by parents in the 1989 GAZEL study questionnaire and dichotomized at the median value, equivalent to the average household income in France at the time (<=1981 vs. >=1981 euros/month)[37;38].

\section{Statistical analysis}

First, we examined sex and age-adjusted associations between employment status and educational level as well as all potential covariates and all substance use outcomes of interest. Second, based on all potential covariates, we calculated Inverse Probability Weights (IPW) of participants' employment status and educational level [39]. The advantage of this method over traditional adjustment for confounding is that it helps target causal inference in an observational study setting. In particular, the use of IPW makes it possible to take into account factors that are associated with the likelihood of being exposed to the independent variable of interest, and can therefore indirectly influence the outcome under study (i.e. selection factors). Thereby, this method simulates random exposure to the independent factor under study - in our setting participants' employment status and educational level [40]. Third, we studied associations between participants' employment and education level and substance use controlling for IPW associated with employment and education level.

We conducted the following secondary analyses: 1 ) we tested the stability of our findings by restricting the study sample to a range of propensity scores that were identical in 
individuals in all three groups studied (never unemployed, unemployed and no higher education, unemployed with higher education): $>$ 10th and $<90$ th percentile of the distribution, $>15$ th and $<85$ th percentile of the distribution and $>20$ th and $<80$ th percentile of the distribution; 2) since substance use levels vary in men and women, we tested for statistical interactions between unemployment and sex; 3 ) we examined whether associations between unemployment and substance use varied with timing of unemployment (<= 2 years prior to 2011 TEMPO study wave) and duration ( $>=1$ year); 4) among individuals who had participated in the TEMPO study in 2011 and in 2009 (n=494) we tested the role of incident unemployment (i.e. the transition from employment to unemployment) in relation to substance use in 2011; 5), we repeated all principal analyses weighing on factors associated with study participation to verify the robustness of our results to correction for selection bias [41].

\section{Results}

Characteristics of the 1126 TEMPO study participants who were in the labour force and whom we included in the analysis are shown in Table 1. Overall, $22.5 \%$ of participants regularly smoked tobacco, $7.1 \%$ were nicotine dependent, $25.3 \%$ regularly drank alcohol, 10.8\% abused alcohol, $16.5 \%$ used cannabis and 5.0\% abused cannabis. Tobacco, alcohol and cannabis use were associated (correlation coefficients above 0.30 were: tobacco use and nicotine dependence: 0.60 , tobacco and cannabis use: 0.39 , tobacco use and cannabis abuse: 0.32 , alcohol use and abuse: 0.33 , alcohol abuse and cannabis use: 0.36 , cannabis use and abuse: 0.52).

As shown in Table 2, controlling for sex and age, participants who experienced unemployment were more likely to use tobacco and cannabis, be dependent to nicotine, and 
abuse alcohol and cannabis than those who were never unemployed. Compared to participants who were never unemployed, those who were ever unemployed and had no higher education were especially likely to smoke tobacco (sex and age-adjusted OR: 2.31, $95 \% \mathrm{Cl} 1.63-3.26$ ), to be nicotine dependent (sex and age-adjusted $\mathrm{OR}: 3.67,95 \% \mathrm{Cl} 2.13-$ 6.33), to use cannabis (sex and age-adjusted OR: $1.75,95 \% \mathrm{Cl} 1.16-2.64$ ) and to abuse cannabis (sex and age-adjusted OR: $2.10,95 \% \mathrm{Cl} 1.10-4.04$ ); those who were ever unemployed and had higher education were most likely to abuse alcohol (sex and ageadjusted OR: $1.87,95 \% \mathrm{Cl} 1.21-2.89$ ) and to use cannabis (sex and age-adjusted OR: 1.55, 95\% Cl 1.07-2.26). Employment status and educational level were not associated with alcohol use therefore this outcome was not carried forward to multivariate analyses.

Tests of sex and age adjusted associations between potential covariates and all study outcomes revealed that a number of characteristics were associated with substance use $(p<0.05)$ : age $<30$ years (alcohol abuse, cannabis use), male sex (all substances), family status other than living with a partner and children (all substances except cannabis abuse), the experience of financial hardship (all substances), recent pregnancy/abortion (tobacco use and nicotine dependence), partner separation (all substance except cannabis abuse), experience of violence (all substances), anxiety/depression (nicotine dependence), hyperactivity/inattention (all substances), juvenile violence/lack of affection (all substances except alcohol abuse and cannabis abuse), antisocial personality (all substances), early smoking initiation (all substances except cannabis abuse), parental tobacco use (tobacco use and nicotine dependence), high parental alcohol use (tobacco use, cannabis use), low parental household income (tobacco use) (Supplementary Table).

Table 3 shows IPW-controlled associations between employment status and educational level and substance use and abuse. Overall, IPW-controlled ORs of employment 
status and educational level and substance use and abuse were higher than those estimated in age and sex-adjusted analyses. Compared to participants who were never unemployed, those who were ever unemployed and had no higher education were more likely to smoke tobacco (OR: 2.76, 95\% Cl 1.14-2.54) and to be nicotine dependent (OR: 5.70, 95\% Cl 3.0310.73), to use cannabis (OR: $2.27,95 \% \mathrm{Cl} 1.42-3.64$ ) and to abuse cannabis (OR: $3.38,95 \% \mathrm{Cl}$ 1.63-7.04). Compared to participants who were never unemployed, those who were ever unemployed and had higher education were more likely to abuse alcohol (OR: $1.89,95 \% \mathrm{Cl}$ 1.16-3.09) and use cannabis (OR: $1.84,95 \% \mathrm{Cl} 1.20-2.83$ ).

Our results were stable in sensitivity analyses that restricted the study sample to a narrower range of propensity score values. Associations between employment status and educational level and substance use and abuse did not vary by sex, except for alcohol abuse which appeared more frequent in women who were ever unemployed and had higher education (age-adjusted OR: $2.41,95 \% \mathrm{Cl} 1.28-4.54$ as compared to $1.47,95 \% \mathrm{Cl} 0.80-2.70$ in men). We found no relationship between duration of unemployment and substance use, however recent unemployment ( $<=2$ years) was more strongly associated with substance use than distal unemployment, although the statistical power of this analysis was limited (results not shown). Similarly, incident unemployment predicted regular tobacco use (OR: 1.91, 95\% Cl: 0.91-4.01), alcohol abuse (OR: 2.53, 95\% 0.96-6.60), cannabis use (OR: 3.91, $95 \% \mathrm{Cl} 1.78-8.56)$ and cannabis abuse (OR: 4.51, 95\% Cl 1.20-16.99). Finally, analyses weighted on factors associated with study participation yielded results similar to our main findings (not shown).

\section{Discussion}

Main findings 
Our study of French young adults drawn from the community shows that tobacco, alcohol and cannabis use and abuse rates are elevated among individuals who experience unemployment and tend to vary with educational level. Compared to the never unemployed, participants who were ever unemployed and had no higher education were 2.27 to 5.70 times more likely to use tobacco or cannabis, to be nicotine-dependent and to abuse cannabis; participants who were ever unemployed and had higher education were 1.84 to 2.14 times more likely to use cannabis, abuse alcohol and be nicotine-dependent. Overall, employment status and educational level appear more strongly associated with substance abuse than with substance use; employment characteristics in young adulthood may influence individuals' subsequent socioeconomic and health trajectories.

\section{Unemployment, educational level and tobacco, alcohol and cannabis}

Young adults are a heterogeneous group characterized by high unemployment rates and sometimes lower occupational grade than can be predicted from family characteristics and educational background. Therefore, measuring SEP in this group is challenging [6;42]. By studying both employment status and educational level, we were able to identify subgroups of individuals with specific patterns of substance use.

Educational level is sometimes considered an indicator of early life socioeconomic circumstances, while unemployment is a marker of adult SEP. In France, as in other industrialized countries, educational level has progressively risen across generations and individuals with low education are disproportionately likely to be unemployed [22;42]. Our finding of elevated levels of tobacco and cannabis use among the unemployed with low education could reflect health selection processes resulting from preexisting addictive behaviors [15;43]. Yet associations between employment status and educational level with 
tobacco and cannabis use increased after accounting for juvenile and parental factors, suggesting that health selection is not the main explanation. Rather, unemployment in and of itself, particularly among youths with low educational level, may increase the levels of substance use. This may reflect several mechanisms: 1) the consequences of an accumulation of disadvantage and stressful circumstances on individuals' health behaviors $[24 ; 44 ; 45] ; 2)$ an enhanced manifestation of individuals' underlying vulnerability to addiction under unfavorable life circumstances [46;47]; 3) the negative consequences of a loss of meaning and diminished sense of control related to unemployment [48]. In our study, unemployment was associated with substance use beyond the influence of financial hardship, social isolation and mental health difficulties, suggesting that such psychological mechanisms may play an important role.

A somewhat unexpected finding of our study is that young adults who had higher education and experienced unemployment were most likely to report alcohol abuse. Prior research has shown especially high levels of alcohol abuse, drunkenness, and binge drinking among French students [6;49], similar to high alcohol abuse rates in students in other countries [50-52]. Our result suggests that high levels of alcohol abuse can persist in some young adults even after they graduate from university, perhaps particularly if they experience difficulties on the labour market.

Overall, the experience of unemployment could lead to increases in substance use, potentially influencing individuals' chances of finding employment [19;43;53;54], and thereby set into motion a vicious circle of unstable employment and substance use and abuse. In times of economic recession, when unemployment rates are high, such phenomena could contribute to widening socioeconomic inequalities in substance use and health. 


\section{Limitations and strengths}

We acknowledge several limitations. First, TEMPO participants had higher levels of education and somewhat lower rates of substance use than young adults in the general population of France [49]. Our main analyses accounted for factors associated with unemployment and our results were stable after correcting for factors associated with study participation, which is reassuring. Nevertheless, we cannot rule out that the association between employment status and educational level and tobacco, alcohol, and cannabis use and abuse in the population at large is stronger than we report. Second, our data were crosssectional, therefore we cannot entirely rule out the possibility that preexisting patterns of substance use influenced participants' employment situation. Analyses based on a subsample of participants showed that incident unemployment was associated with usage of tobacco, alcohol and cannabis, suggesting that changes in employment status can precede changes in substance use patterns, but the existence of a causal link between unemployment and substance use will need to be studied in prospective cohort studies.

The main strengths of our study are: a) a community based socioeconomically varied sample of young adults; b) use of IPW to account for multiple factors associated with employment status and educational level including parental characteristics ascertained directly from participants' parents; c) a systematic comparison of several substance use and abuse outcomes.

Conclusion

Levels of substance use in young adults who experience unemployment are high and vary with educational level. To understand the underlying processes, there is need for additional longitudinal research on variations in substance use as individuals transition from 
higher education to the labor market and in an out of employment, particularly in times of economic recession. 
Role of funding source: This research was funded by the French Ministry of Health-IReSP (TGIR Cohortes), the French Inter-departmental Mission for the Fight against Drugs and Drug addiction (MILDT), The French Institute of Cancer (INCa). Maria Melchior is the recipient of a Young Researcher Award from the French National Research Agency (ANR).

Contributors: MM had the original idea for the study, was responsible for data collection, and wrote the first draft of the manuscript. GE and AC were responsible for data collection and management and performed statistical analyses. CG and NY helped interpret the study data and took part in writing the manuscript.

\section{Conflict of interest: none}

Acknowledgements: The authors wish to thank study participants as well as their parents who helped collect data for this investigation. We are grateful to the GAZEL study team for help in implementing the Tempo cohort, to Jean-François Chastang for help with calculating study weights, to Alice Guéguen for assistance in calculating inverse probability weights, and to Professor France Lert for many rich discussions on social determinants of substance use, which helped shape this manuscript. 


\section{References}

1 Perkonigg A, Pfister H, Hofler M, Frohlich C, Zimmermann P, Lieb R, Wittchen HU: Substance use and substance use disorders in a community sample of adolescents and young adults: incidence, age effects and patterns of use. European Addiction Research 2006;12:187-196.

2 Melchior M, Chastang J-F, Goldberg P, Fombonne E: High prevalence rates of tobacco, alcohol and drug use in adolescents and young adults in France: results from the GAZEL Youth study. Addictive Behaviors 2008;33:122-133.

3 EMCDDA: The state of the drugs problem in Europe.; 2012.

4 Arnett JJ: Emerging adulthood. A theory of development from the late teens through the twenties. American Psychologist 2000;55:469-480.

5 Sussman S, Arnett JJ: Emerging Adulthood: Developmental Period Facilitative of the Addictions. Evaluation and the Health Professionals 2014.

6 Redonnet B, Cholet A, Bowes L, Melchior M: Tobacco, alcohol and drug-use among young adults in France: the socioeconomic context. Drug and Alcohol Dependence 2012;121:231-239.

7 Vinther-Larsen M, Huckle T, You R, Casswell S: Area level deprivation and drinking patterns among adolescents. Health and Place 2013;19:53-58.

8 Patrick ME, Wightman P, Schoeni RF, Schulenberg JE: Socioeconomic status and substance use among young adults: a comparison across constructs and drugs. Journal of Studies on Alcohol and Drugs 2012;73:772-782.

9 Tjora T, Hetland J, Aaro LE, Wold B, Overland S: Late-onset smokers: how many, and associations with health behaviours and socioeconomic status. Scandinavian Journal of Public Health 2012;40:537-543.

10 Christakis NA, Fowler JH: The collective dynamics of smoking in a large social network. New England Journal of Medicine 2008;358:2249-2258.

11 Rosenquist JN, Murabito J, Fowler JH, Christakis NA: The spread of alcohol consumption behavior in a large social network. Annals of Internal Medicine 2010;152:426-33, W141.

12 Odgers CL, Moffitt TE, Broadbent JM, Dickson N, Hancox RJ, Harrington H, Poulton R, Sears MR, Thomson WM, Caspi A: Female and male antisocial trajectories: from childhood origins to adult outcomes. Development and Psychopathology 2008;20:673-716.

13 Legleye S, Beck F, Khlat M, Peretti-Watel P, Chau N: The influence of socioeconomic status on cannabis use among French adolescents. Journal of Adolescent Health 2012;50:395-402.

14 Lee JO, Herrenkohl TI, Kosterman R, Small CM, Hawkins JD: Educational inequalities in the cooccurrence of mental health and substance use problems, and its adult socio-economic consequences: a longitudinal study of young adults in a community sample. Public Health 2013;127:745-753.

15 Horwood L, Fergusson DM, Hayatbakhsh MR, Najman JM, Coffey C, Patton GC, Silins E, Hutchinson DM: Cannabis use and educational achievement: findings from three Australasian cohort studies. Drug and Alcohol Dependence 2010;110:247-253. 
16 McCaffrey DF, Pacula RL, Han B, Ellickson P: Marijuana use and high school dropout: the influence of unobservables. Health Economics 2010;19:1281-1299.

17 Prochaska JJ, Shi Y, Rogers A: Tobacco use among the job-seeking unemployed in California. Preventive Medicine 2013;56:329-332.

18 Popovici I, French MT: Does Unemployment Lead to Greater Alcohol Consumption? Industrial Relations 2013;52:444-466.

19 Henkel D: Unemployment and substance use: a review of the literature (1990-2010). Current Drug Abuse Review 2011;4:4-27.

20 Bor J, Basu S, Coutts A, McKee M, Stuckler D: Alcohol use during the great recession of 20082009. Alcohol \& Alcoholis 2013;48:343-348.

21 Gili M, Roca M, Basu S, McKee M, Stuckler D: The mental health risks of economic crisis in Spain: evidence from primary care centres, 2006 and 2010. European Journal of Public Health 2013;23:103-108.

22 OECD: Youth unemployment. http://www oecd-ilibrary org/employment/youth-unemploymentrate_20752342-table2.

23 OECD: How does educational attainment affect participation in the labour market? http://www oecd org/education/skills-beyond-school/48630772 pdf.

24 Bowes L, Chollet A, Fombonne E, Galéra C, Melchior M: Lifecourse socioeconomic position and tobacco and cannabis use among young adults. European Journal of Public Health 2013;23:322-327.

25 Goldberg M, Leclerc A, Bonenfant S, Chastang JF, Schmaus A, Kaniewski N, Zins M: Cohort profile: the GAZEL Cohort Study. Int J Epidemiol 2007;36:32-39.

26 Fombonne E, Vermeersch S: Les enfants de la cohorte GAZEL: I--Prevalence des contacts avec le système medico-educatif pour raisons psychologiques, et facteurs associes. Rev Epidemiol Sante Publique 1997; 45:29-40.

27 Heatherton TF, Kozlowski LT, Frecker RC, Fagerstrom KO: The Fagerstrom Test for Nicotine Dependence: a revision of the Fagerstrom Tolerance Questionnaire. British Journal of Addiction 1991;86:1119-1127.

28 Babor T, Higgins-Biddle JC, Saunders JB, Monteiro MG: AUDIT: the Alcohol Use Disorders Identification Test. http://whqlibdoc who int/hq/2001/WHO_MSD_MSB_01 6a pdf.

29 Legleye S, Piontek D, Kraus L: Psychometric properties of the Cannabis Abuse Screening Test (CAST) in a French sample of adolescents. Drug and Alcohol Dependence 2010;113:229-235.

30 Ministère de l'Education Nationale: Résultats définitifs du baccalauréat 2011. http://www education gouv $\mathrm{fr} / \mathrm{cid} 55597 /$ resultats-definitifs-du-baccalaureat $\mathrm{html}$.

31 Melchior M, Berkman LF, Niedhammer I, Chea M, Goldberg M: Social relations and self-reported health: a prospective analysis of the French Gazel cohort. Social Science \& Medicine 2003;56:1817-1830. 
32 Beck F, Cavalin C, Maillochon F: Violences et santé en France: état des lieux. La documentation française., 2010.

33 Sheehan DV, Lecrubier Y, Sheehan KH, Amorim P, Janavs J, Weiller E, Hergueta T, Baker R, Dunbar GC: The Mini-International Neuropsychiatric Interview (M.I.N.I.): the development and validation of a structured diagnostic psychiatric interview for DSM-IV and ICD-10. J Clin Psychiatry 1998;59 Suppl;::22-33.

34 Kessler RC, Adler LA, Gruber MJ, Sarawate CA, Spencer T, Van Brunt DL: Validity of the World Health Organization Adult ADHD Self-Report Scale (ASRS) Screener in a representative sample of health plan members. International Journal of Methods in Psychiatric Research 2007;16:52-65.

35 Roustit C, Renahy E, Guernec G, Lesieur S, Parizot I, Chauvin P: Exposure to interparental violence and psychosocial maladjustment in the adult life course: advocacy for early prevention. Journal of Epidemiology and Community Health 2009;63:563-568.

36 Maxwell ME: Family Interview for Genetic Studies (FIGS): A Manual for FIGS. Bethesda, Maryland, Clinical Neurogenetics Branch, Intramural Research Program, National Institute of Mental Health, 1992.

37 INSEE: Revenu disponible par ménage (moyenne et médiane). http://81 25568 41/fr/themes/tableau asp?reg_id=0\&ref_id=NATSOS04202.

38 Melchior M, Chastang J-F, Walburg V, Galéra C, Fombonne E: Family income and youths' symptoms of depression and anxiety: a longitudinal study of the GAZEL Youth cohort. Depression and Anxiety 2010;27:1095-1103.

39 Hernan M, Robbins J: IP weighting and marginal structural models.; Causal Inference. 2013, pp 11-21.

40 Hernan M, Robbins J: Randomized experiments.; Causal Inference. 2013, pp 13-20.

41 Deville J, Sarndal C-E: Calibration estimators in survey sampling. Journal of the American Statistical Association 1992;87:376-382.

42 Lynch J, Kaplan GA: Socioeconomic position.; in Berkman LF, Kawachi I, (eds): Social Epidemiology. New York, Oxford Press, 2000, pp 13-35.

43 Hyggen C: Does smoking cannabis affect work commitment? Addiction 2012;107:1309-1315.

44 Lynch JW, Kaplan GA, Shepton SE: Cumulative impact of sustained economic hardship on physical, cognitive, psychological, and social functionning. N Engl J Med 1997;337:1889-1895.

45 Luoto R, Poikolainen K, Uutela A: Unemployment, sociodemographic background and consumption of alcohol before and during the economic recession of the 1990s in Finland. International Journal of Epidemiology 1998;27:623-629.

Agrawal A, Lynskey MT: Are there genetic influences on addiction: evidence from family, adoption and twin studies. Addiction 2008;103:1069-1081. 
47 Kendler KS, Schmitt E, Aggen SH, Prescott CA: Genetic and environmental influences on alcohol, caffeine, cannabis, and nicotine use from early adolescence to middle adulthood. Archives of General Psychiatry 2008;65:674-682.

48 Backhans MC, Hemmingsson T: Unemployment and mental health--who is (not) affected? European Journal of Public Health 2012;22:429-433.

49 Beck F, Tovar M-L, Spilka S, Guignard R, Richard J-B: Les niveaux d'usage de drogues en France en 2010. http://www inpes sante fr/Barometres/barometre-sante2010/pdf/Tendances\%2076\%20-\%20BaroVF pdf.

50 Wechsler $\mathrm{H}$, Lee JE, Kuo M, Seibring M, Nelson TF, Lee H: Trends in college binge drinking during a period of increased prevention efforts. Findings from 4 Harvard School of Public Health College Alcohol Study surveys: 1993-2001. Journal of American College Health 2002;50:203217.

51 Heather N, Partington S, Partington E, Longstaff F, Allsop S, Jankowski M, Wareham H, St Clair GA: Alcohol use disorders and hazardous drinking among undergraduates at English universities. Alcohol \& Alcoholism 2011;46:270-277.

52 Sanchez ZM, Locatelli DP, Noto AR, Martins SS: Binge drinking among Brazilian students: a gradient of association with socioeconomic status in five geo-economic regions. Drug and Alcohol Dependence 2013;127:87-93.

53 Woodhead EL, Cronkite RC, Moos RH, Timko C: Coping Strategies Predictive of Adverse Outcomes among Community Adults. Journal of Clinical Psychology 2013.

54 Nemeth Z, Urban R, Kuntsche E, San Pedro EM, Roales Nieto JG, Farkas J, Futaki L, Kun B, Mervo B, Olah A, Demetrovics Z: Drinking motives among Spanish and Hungarian young adults: a cross-national study. Alcohol and Alcoholism 2011;46:261-269. 
Tables 
20/05/2014 Unemployment and substance use in young adults

Table 1. Characteristics of TEMPO study participants (France, $n=1126,2011,20-37$ years of age, \%, \% in men and women, p-value).

\begin{tabular}{|c|c|c|c|c|}
\hline & $\begin{array}{c}\text { Total } \\
n=1126\end{array}$ & $\begin{array}{c}\text { Men } \\
n=427\end{array}$ & $\begin{array}{c}\text { Women } \\
n=699\end{array}$ & Women vs. men p-value \\
\hline \multicolumn{5}{|l|}{ History of unemployment / educational level : } \\
\hline Never unemployed and no higher education & 17.2 & 19.7 & 15.7 & \\
\hline Never unemployed and higher education & 35.4 & 33.3 & 36.6 & \\
\hline Unemployed and no higher education & 19.7 & 20.2 & 19.5 & \\
\hline Unemployed and higher education & 27.7 & 26.9 & 28.2 & 0.41 \\
\hline \multicolumn{5}{|l|}{ Demographic characteristics } \\
\hline Age $:<30$ & 28.2 & 29.0 & 27.6 & \\
\hline$>=30$ & 71.8 & 71.0 & 72.4 & 0.61 \\
\hline \multicolumn{5}{|l|}{ Family status : } \\
\hline Lives with a partner and children & 44.3 & 37.7 & 48.3 & 0.0005 \\
\hline Lives with a partner, no children & 26.6 & 27.9 & 25.8 & 0.43 \\
\hline Does not live with a partner & 29.1 & 34.4 & 25.9 & 0.002 \\
\hline Financial hardship : No & 82.4 & 85.0 & 80.8 & \\
\hline Yes & 17.6 & 15.0 & 19.2 & 0.07 \\
\hline Social support : Sufficient & 74.3 & 84.5 & 68.0 & \\
\hline Insufficient & 25.7 & 15.5 & 32.0 & $<.0001$ \\
\hline \multicolumn{5}{|l|}{ Life events } \\
\hline Pregnancy / abortion : No & 76.2 & 80.9 & 73.3 & \\
\hline Yes & 23.8 & 19.1 & 26.7 & 0.004 \\
\hline Partner separation : No & 91.5 & 90.7 & 91.9 & \\
\hline Yes & 8.5 & 9.3 & 8.1 & 0.50 \\
\hline Violence : No & 68.6 & 66.9 & 69.7 & \\
\hline Yes & 31.4 & 33.1 & 30.3 & 0.33 \\
\hline \multicolumn{5}{|l|}{ Psychological factors } \\
\hline Anxiety / depression : No & 75.4 & 81.0 & 72.0 & \\
\hline Yes & 24.6 & 19.0 & 28.0 & 0.0006 \\
\hline Hyperactivity / inattention : No & 93.0 & 91.1 & 94.1 & \\
\hline Yes & 7.0 & 8.9 & 5.9 & 0.05 \\
\hline \multicolumn{5}{|l|}{ Chronic disease } \\
\hline Chronic disease : No & 85.3 & 90.4 & 82.1 & \\
\hline Yes & 14.7 & 9.6 & 17.9 & 0.0001 \\
\hline \multicolumn{5}{|l|}{ Juvenile characteristics } \\
\hline Violence / lack of affection : No & 59.8 & 61.0 & 59.1 & \\
\hline Yes & 40.2 & 39.0 & 40.9 & 0.52 \\
\hline Antisocial personality : No & 85.5 & 84.5 & 86.1 & \\
\hline Yes & 14.5 & 15.5 & 13.9 & 0.46 \\
\hline Early smoking initiation : No & 85.2 & 85.2 & 85.3 & \\
\hline Yes & 14.8 & 14.8 & 14.7 & 0.96 \\
\hline \multicolumn{5}{|l|}{ Parental characteristics } \\
\hline Tobacco use : No & 68.5 & 66.5 & 69.8 & \\
\hline Yes & 31.5 & 33.5 & 30.2 & 0.26 \\
\hline High alcohol use : No & 77.3 & 76.3 & 77.8 & \\
\hline Yes & 22.7 & 23.7 & 22.2 & 0.57 \\
\hline Household income : High & 63.7 & 66.0 & 62.3 & \\
\hline Intermediate / Low & 36.3 & 34.0 & 37.7 & 0.22 \\
\hline \multicolumn{5}{|l|}{ Adult substance use } \\
\hline Regular tobacco use & 22.5 & 27.0 & 19.7 & 0.005 \\
\hline Nicotine dependence & 7.1 & 7.8 & 6.7 & 0.03 \\
\hline Regular alcohol use & 25.3 & 38.3 & 17.5 & $<.0001$ \\
\hline Alcohol abuse & 10.8 & 16.4 & 7.3 & $<.0001$ \\
\hline Cannabis use & 16.5 & 23.7 & 12.0 & $<.0001$ \\
\hline Cannabis abuse & 5.0 & 7.3 & 3.6 & 0.006 \\
\hline
\end{tabular}


Table 2. History of unemployment, educational level and substance use among TEMPO study participants (France, n=1126, 2011, 20-37 years of age, 2011, age and sex-adjusted ORs, $95 \% \mathrm{Cl}$, $\mathrm{p}$-value) ${ }^{1}$.

\begin{tabular}{|c|c|c|c|c|c|c|}
\hline & Regular tobacco use & Nicotine dependence & Regular alcohol use & Alcohol abuse & Cannabis use & Cannabis abuse \\
\hline $\begin{array}{l}\text { History of unemployment : } \\
\text { Never unemployed } \\
\text { Unemployed }\end{array}$ & $\begin{array}{c}1 \\
1.49(1.12-1.98) \text { * }\end{array}$ & $\begin{array}{c}1 \\
2.45(1.51-3.97) \text { ** }\end{array}$ & $\begin{array}{c}1 \\
0.85(0.64-1.12) \mathrm{NS}\end{array}$ & $\begin{array}{c}1 \\
1.65(1.12-2.44)^{*}\end{array}$ & $\begin{array}{c}1 \\
1.63(1.18-2.26)^{* *}\end{array}$ & $\begin{array}{c}1 \\
1.66(0.96-2.88) \text { NS }\end{array}$ \\
\hline $\begin{array}{l}\text { Educational level : } \\
\text { Higher education } \\
\text { No higher education }\end{array}$ & $\begin{array}{c}1 \\
2.47(1.85-3.29) * * \star\end{array}$ & $\begin{array}{c}1 \\
2.34(1.47-3.71) \text { ** }\end{array}$ & $\begin{array}{c}1 \\
0.67(0.50-0.90) \text { ** }\end{array}$ & $\begin{array}{c}1 \\
0.92(0.61-1.37) \text { NS }\end{array}$ & $\begin{array}{c}1 \\
1.10(0.79-1.53) \text { NS }\end{array}$ & $\begin{array}{c}1 \\
1.61(0.94-2.78) \mathrm{NS}\end{array}$ \\
\hline $\begin{array}{l}\text { History of unemploymentleducational level : } \\
\text { Never unemployed } \\
\text { Unemployed with no higher education } \\
\text { Unemployed with higher education }\end{array}$ & $\begin{array}{c}1 \\
2.31(1.63-3.26) * * * \\
1.03(0.73-1.46) \mathrm{NS}\end{array}$ & $\begin{array}{c}1 \\
3.67(2.13-6.33) * * * \\
1.65(0.92-2.97) \mathrm{NS}\end{array}$ & $\begin{array}{c}1 \\
0.69(0.47-1.02) \mathrm{NS} \\
0.97(0.70-1.34) \mathrm{NS}\end{array}$ & $\begin{array}{c}1 \\
1.36(0.81-2.30) \mathrm{NS} \\
1.87(\mathbf{1 . 2 1}-2.89)^{*}\end{array}$ & $\begin{array}{c}1 \\
1.75(1.16-2.64) * \\
1.55(1.07-2.26)^{*}\end{array}$ & $\begin{array}{c}1 \\
2.10(1.10-4.04) * \\
1.36(0.71-2.63) \mathrm{NS}\end{array}$ \\
\hline
\end{tabular}

\footnotetext{
${ }^{1}$ p-value: NS: statistically not significant; *: $<0.05-0.01 ; * *: 0.01-0.001 ; * * *:<0.0001$
} 
Table 3. History of unemployment and educational status and substance use in the TEMPO (Inverse probability weights-controlled ORs, 95\% Cl) ${ }^{1,2}$.

\begin{tabular}{|c|c|c|c|c|c|}
\hline & $\begin{array}{c}\text { Regular } \\
\text { tobacco use }\end{array}$ & $\begin{array}{c}\text { Nicotine } \\
\text { dependence }\end{array}$ & Alcohol abuse & Cannabis use & Cannabis abuse \\
\hline Never unemployed & 1 & 1 & 1 & 1 & 1 \\
\hline Unemployed with no higher education & $2.76(1.86-4.10) * *$ & $5.70(3.03-10.73) * * *$ & $1.64(0.91-2.93) \mathrm{NS}$ & $2.27(1.42-3.64) * *$ & $3.38(1.63-7.04) * *$ \\
\hline Unemployed with higher education & $1.15(0.77-1.71) \mathrm{NS}$ & $2.14(1.10-4.18) * * \star$ & $1.89(1.16-3.09)$ * & $1.84(1.20-2.83)$ ** & $1.90(0.91-3.96) \mathrm{NS}$ \\
\hline
\end{tabular}

${ }^{1}$ Multivariate analyses are controlled for inverse probability weights based on participants' age, sex, family status, financial hardship, lack of

social support, pregnancy/abortion, partner separation, exposure to violence, depression/anxiety, hyperactivity/inattention, juvenile violence/lack of affection, antisocial personality, early smoking initiation, parental tobacco use, parental high alcohol use, household family income.

${ }^{2}$ p-value: NS: statistically not significant; *: $<0.05-0.01 ; * *: 0.01-0.001 ; * * *:<0.0001$ 
Supplementary Table . Demographic characteristics, life events, psychological factors, chronic disease, juvenile and family characteristics and substance use in the TEMPO study (France, $n=1126,2011,20-37$ years of age, age and sex-adjusted ORs, 95\% Cl, p-value).

\begin{tabular}{|c|c|c|c|c|c|}
\hline Demographic characteristics & $\begin{array}{l}\text { Regular } \\
\text { tobacco use }\end{array}$ & $\begin{array}{c}\text { Nicotine } \\
\text { dependence }\end{array}$ & Alcohol abuse & Cannabis use & Cannabis abuse \\
\hline Age $\begin{aligned}: & <30 \\
& >=30\end{aligned}$ & $\begin{array}{c}1 \\
0.85(0.63-1.16) \\
p=0.31\end{array}$ & $\begin{array}{c}1 \\
0.97(0.59-1.60) \\
p=0.91\end{array}$ & $\begin{array}{c}1 \\
0.42(0.29-0.62) \\
p=<.0001\end{array}$ & $\begin{array}{c}1 \\
0.64(0.46-0.90) \\
p=0.01\end{array}$ & $\begin{array}{c}1 \\
0.76(0.43-1.35) \\
p=0.35\end{array}$ \\
\hline Sex : Female & 1 & 1 & 1 & 1 & 1 \\
\hline Male & $\begin{array}{c}1.50(1.13-1.99) \\
p=0.005\end{array}$ & $\begin{array}{c}1.17(0.73-1.85) \\
p=0.52\end{array}$ & $\begin{array}{c}2.50(1.70-3.69) \\
p=<.0001\end{array}$ & $\begin{array}{c}2.27(1.65-3.12) \\
p=<.0001\end{array}$ & $\begin{array}{c}2.11(1.23-3.62) \\
p=0.007\end{array}$ \\
\hline \multicolumn{6}{|l|}{ Family status : } \\
\hline Lives with a partner and children & 1 & 1 & 1 & 1 & 1 \\
\hline Lives with a partner, no children & $0.82(0.56-1.20)$ & $1.06(0.56-2.02)$ & $1.44(0.85-2$ & $1.54(1.01-2.36)$ & $0.81(0.39-1.68)$ \\
\hline Does not live with a partner & $\begin{array}{c}1.31(0.92-1.86) \\
p=0.05\end{array}$ & $\begin{array}{c}2.12(1.22-3.68) \\
\quad p=0.01\end{array}$ & $\begin{array}{c}1.69(1.02-2.79) \\
p=0.12\end{array}$ & $\begin{array}{c}1.86(1.24-2.80) \\
p=0.01\end{array}$ & $\begin{array}{c}1.09(0.56-2.14) \\
p=0.71\end{array}$ \\
\hline $\begin{array}{r}\text { Financial hardship : No } \\
\text { Yes }\end{array}$ & $\begin{array}{c}1 \\
1.85(1.31-2.61) \\
p=0.0005\end{array}$ & $\begin{array}{c}1 \\
3.42(2.10-5.56) \\
p=<.0001\end{array}$ & $\begin{array}{c}1 \\
1.72(1.09-2.71) \\
p=0.02\end{array}$ & $\begin{array}{c}1 \\
2.22(1.52-3.24) \\
p=<.0001\end{array}$ & $\begin{array}{c}1 \\
2.45(1.35-4.42) \\
p=0.003\end{array}$ \\
\hline $\begin{array}{l}\text { Social support : Sufficient } \\
\text { Insufficient }\end{array}$ & $\begin{array}{c}1 \\
1.32(0.96-1.82) \\
p=0.09\end{array}$ & $\begin{array}{c}1 \\
1.50(0.91-2.47) \\
p=0.11\end{array}$ & $\begin{array}{c}1 \\
1.24(0.79-1.94) \\
p=0.35\end{array}$ & $\begin{array}{c}1 \\
1.27(0.88-1.85) \\
p=0.20\end{array}$ & $\begin{array}{c}1 \\
1.68(0.93-3.06) \\
p=0.09\end{array}$ \\
\hline \multicolumn{6}{|l|}{ Life events } \\
\hline $\begin{array}{r}\text { Pregnancy / abortion : No } \\
\text { Yes }\end{array}$ & $\begin{array}{c}1 \\
0.58(0.40-0.84) \\
p=0.004\end{array}$ & $\begin{array}{c}1 \\
0.44(0.22-0.87) \\
p=0.02\end{array}$ & $\begin{array}{c}1 \\
1.30(0.82-2.06) \\
p=0.26\end{array}$ & $\begin{array}{c}1 \\
0.74(0.49-1.12) \\
p=0.16\end{array}$ & $\begin{array}{c}1 \\
0.97(0.50-1.89) \\
p=0.93\end{array}$ \\
\hline $\begin{array}{r}\text { Partner separation : No } \\
\text { Yes }\end{array}$ & $\begin{array}{c}1 \\
2.35(1.50-3.66) \\
p=0.0002\end{array}$ & $\begin{array}{c}1 \\
2.05(1.06-3.97) \\
p=0.03\end{array}$ & $\begin{array}{c}1 \\
1.79 \begin{array}{c}(1.01-3.17) \\
p=0.05\end{array}\end{array}$ & $\begin{array}{c}1 \\
1.88(1.14-3.08) \\
p=0.01\end{array}$ & $\begin{array}{c}1 \\
1.47(0.64-3.38) \\
p=0.37\end{array}$ \\
\hline $\begin{array}{r}\text { Violence : No } \\
\text { Yes }\end{array}$ & $\begin{array}{c}1 \\
1.79(1.34-2.40) \\
p=<.0001\end{array}$ & $\begin{array}{c}1 \\
2.35(1.48-3.72) \\
p=0.005\end{array}$ & $\begin{array}{c}1 \\
1.89(1.28-2.80) \\
p=0.001\end{array}$ & $\begin{array}{c}1 \\
1.54(1.11-2.15) \\
p=0.01\end{array}$ & $\begin{array}{c}1 \\
1.75(1.01-3.03) \\
p=0.04\end{array}$ \\
\hline \multicolumn{2}{|l|}{ Psychological factors } & 1 & 1 & 1 & 1 \\
\hline & $\begin{array}{c}1.32(0.96-1.82) \\
p=0.09\end{array}$ & $\begin{array}{c}2.00(1.24-3.22) \\
p=0.01\end{array}$ & $\begin{array}{c}1.27(0.82-1.97) \\
p=0.28\end{array}$ & $\begin{array}{c}1.14(0.79-1.66) \\
p=0.47\end{array}$ & $\begin{array}{c}0.99(0.52-1.90) \\
p=0.99\end{array}$ \\
\hline $\begin{array}{r}\text { Hyperactivity / inattention : No } \\
\text { Yes }\end{array}$ & $\begin{array}{c}1 \\
2.42(1.50-3.90) \\
p=0.0003\end{array}$ & $\begin{array}{c}1 \\
2.55(1.31-4.96) \\
p=0.01\end{array}$ & $\begin{array}{c}1 \\
1.73(0.94-3.21) \\
p=0.08\end{array}$ & $\begin{array}{c}1 \\
2.14(1.27-3.60) \\
p=0.004\end{array}$ & $\begin{array}{c}1 \\
2.11(0.95-4.68) \\
p=0.07\end{array}$ \\
\hline $\begin{array}{r}\text { Chronic disease : No } \\
\text { Yes }\end{array}$ & $\begin{array}{c}1 \\
1.26(0.85-1.86) \\
p=0.25\end{array}$ & $\begin{array}{c}1 \\
1.52(0.90-2.52) \\
p=0.12\end{array}$ & $\begin{array}{c}1 \\
1.02(0.57-1.82) \\
p=0.95\end{array}$ & $\begin{array}{c}1 \\
0.88(0.54-1.44) \\
p=0.62\end{array}$ & $\begin{array}{c}1 \\
0.79(0.33-1.89) \\
p=0.59\end{array}$ \\
\hline \multicolumn{6}{|l|}{ Juvenile characteristics } \\
\hline $\begin{array}{r}\text { Violence / lack of affection : No } \\
\text { Yes }\end{array}$ & $\begin{array}{c}1 \\
1.54(1.16-2.04) \\
p=0.003\end{array}$ & $\begin{array}{c}1 \\
2.13(1.34-3.38) \\
p=0.001\end{array}$ & $\begin{array}{c}1 \\
1.41(0.96-2.08) \\
p=0.08\end{array}$ & $\begin{array}{c}1 \\
1.57(1.14-2.17) \\
p=0.006\end{array}$ & $\begin{array}{c}1 \\
1.42(0.83-2.44) \\
p=0.21\end{array}$ \\
\hline $\begin{array}{r}\text { Antisocial personality : No } \\
\text { Yes }\end{array}$ & $\begin{array}{c}1 \\
2.36(1.65-3.38) \\
p=<.0001\end{array}$ & $\begin{array}{c}1 \\
2.43(1.44-4.10) \\
p=0.0009\end{array}$ & $\begin{array}{c}1 \\
2.49(1.59-3.91) \\
p=<.0001\end{array}$ & $\begin{array}{c}1 \\
2.34(1.58-3.46) \\
p=<.0001\end{array}$ & $\begin{array}{c}1 \\
2.20(1.18-4.09) \\
p=0.01\end{array}$ \\
\hline $\begin{array}{r}\text { Early smoking initiation: No } \\
\text { Yes }\end{array}$ & $\begin{array}{c}1 \\
1.83(1.27-2.63) \\
p=0.001\end{array}$ & $\begin{array}{c}1 \\
2.95(1.77-4.89) \\
p=<.0001\end{array}$ & $\begin{array}{c}1 \\
1.59(0.98-2.58) \\
p=0.06\end{array}$ & $\begin{array}{c}1 \\
2.75(1.87-4.04) \\
p=<.0001\end{array}$ & $\begin{array}{c}1 \\
1.78(0.93-3.40) \\
0.08\end{array}$ \\
\hline \multicolumn{6}{|l|}{ Parental characteristics } \\
\hline $\begin{aligned} & \text { Tobacco use : } \text { No } \\
& \text { Yes }\end{aligned}$ & $\begin{array}{c}1 \\
1.84(1.36-2.49) \\
p=<.0001\end{array}$ & $\begin{array}{c}1 \\
1.60(0.99-2.58) \\
p=0.05\end{array}$ & $\begin{array}{c}1 \\
1.43(0.94-2.17) \\
p=0.09\end{array}$ & $\begin{array}{c}1 \\
1.42(1.01-2.01) \\
p=0.05\end{array}$ & $\begin{array}{c}1 \\
1.46(0.81-2.63) \\
p=0.21\end{array}$ \\
\hline $\begin{array}{r}\text { High alcohol use : No } \\
\text { Yes }\end{array}$ & $\begin{array}{c}1 \\
1.38(1.00-1.90) \\
p=0.05\end{array}$ & $\begin{array}{c}1 \\
1.50(0.91-2.47) \\
p=0.11\end{array}$ & $\begin{array}{c}1 \\
1.32(0.85-2.06) \\
p=0.21\end{array}$ & $\begin{array}{c}1 \\
1.44(1.00-2.08) \\
p=0.05\end{array}$ & $\begin{array}{c}1 \\
1.39(0.76-2.54) \\
p=0.28\end{array}$ \\
\hline $\begin{array}{l}\text { Household Income : } \\
\text { High } \\
\text { Intermediate / Low }\end{array}$ & $\begin{array}{c}1 \\
1.37(1.02-1.83) \\
p=0.03\end{array}$ & $\begin{array}{c}1 \\
1.51(0.94-2.40) \\
p=0.09\end{array}$ & $\begin{array}{c}1 \\
0.55(0.35-0.86) \\
p=0.009\end{array}$ & $\begin{array}{c}1 \\
0.78(0.55-1.10) \\
p=0.16\end{array}$ & $\begin{array}{c}1 \\
1.24(0.71-2.17) \\
p=0.45\end{array}$ \\
\hline
\end{tabular}


Figure1. TEMPO cohort study flow-chart (1991-2011)

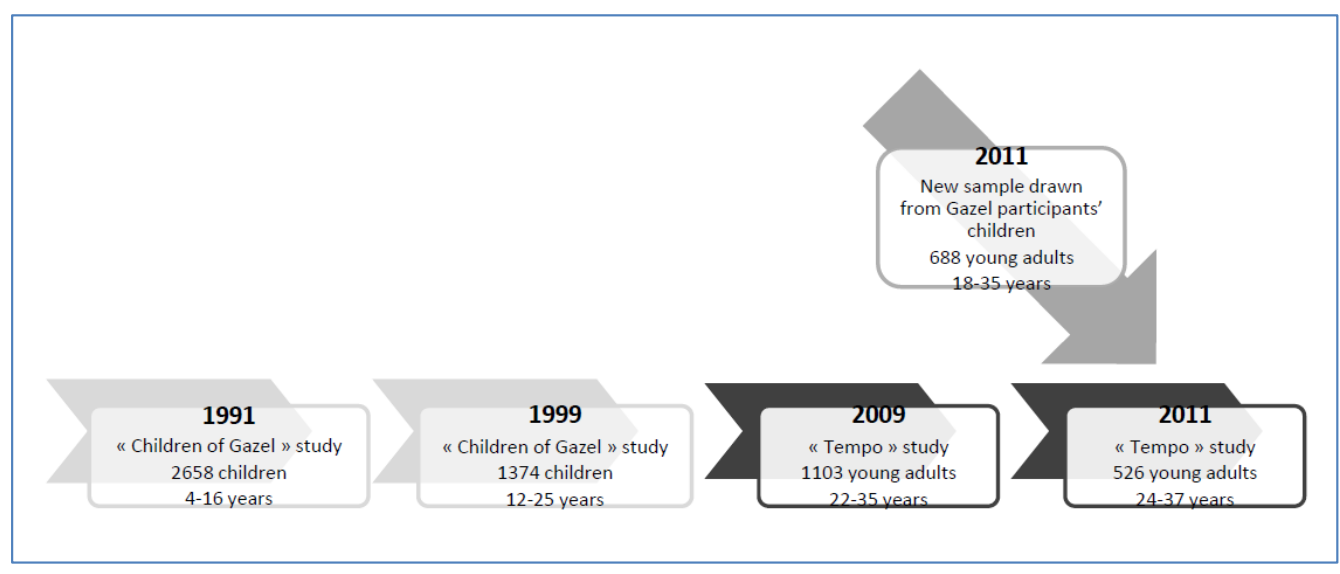

